\title{
PENGARUH SOSIAL EKONOMI DAN FASILITAS BELAJAR TERHADAP PENGUASAAN KONSEP MATEMATIKA SISWA SMPN KECAMATAN KEMAYORAN
}

\author{
Aulia Masruroh \\ Universitas Indraprasta PGRI \\ aulia.m89@gmail.com
}

\begin{abstract}
Abstrak
Status sosial ekonomi orangtua memiliki peran terhadap penguasaan konsep siswa. Pemenuhan fasilitas belajar yang baik dapat mendorong siswa untuk rajin belajar. Fasilitas belajar sangat mempengaruhi penguasaan konsep siswa karena pemenuhan fasilitas belajar yang memadai dan lengkap akan mendorong siswa untuk mendapat hasil yang maksimal. Penelitian ini merupakan penelitian kuantitatif dengan metode survei yang bertujuan (1) untuk mengetahui pengaruh langsung sosial ekonomi orang tua terhadap penguasaan fasilitas belajar (2) mengetahui pengaruh langsung sosial ekonomi orangtua terhadap fasilitas belajar (3) mengetahui pengaruh langsung fasilitas belajar terhadap penguasaan konsep matematika, (4) mengathui pengaruh tidak langsung sosial ekonomi orangtua terhadap penguasaan konsep matematika melalui fasilitas belajar. Sampel penelitian adalah siswa kelas VIII dari tiga Sekolah Menengah Pertama di Kecamatan Kemayoran Jakarta Pusat yaitu SMP Negeri 22838 siswa, SMP Negeri 26923 siswa, dan SMP Negeri 7927 siswa, total jumlah sampel 88 siswa. Instrumen yang digunakan yaitu lembar kuesioner dan tes. Analisis data dengan menggunakan metode analisis jalur. Uji statistik yang digunakan uji t. Hasil penelitian menunjukkan: (1) Terdapat pengaruh langsung yang signifikan sosial ekonomi orang tua terhadap penguasaan konsep matematika. (2) Terdapat pengaruh langsung yang signifikan sosial ekonomi orang tua terhadap fasilitas belajar 423. (3) Terdapat pengaruh langsung yang signifikan fasilitas belajar terhadap penguasaan konsep matematika siswa dengan koefisien jalur sebesar 0,548. (4) Terdapat pengaruh tidak langsung sosial ekonomi orang tua terhadap penguasaan konsep matematika melalui fasilitas belajar dengan koefisien jalur sebesar 0,232.
\end{abstract}

Kata kunci: sosial ekonomi orangtua, fasilitas belajar, konsep matematika

\begin{abstract}
Socio economic status of parents have a role for the mastery of student concept. A fullfillmemnt the studt facility can encourage student for study hhard. Facility for study have a influence for student mastery of concept because a fulfillment of learning facility will make the student get a maximum result. This research is a quantitative research with survey research which aims [1] to know how a socio economic status from parent have a influence for mastery of learning facility (2) to know how a socio economic status of parent to learning facility [3] to know how learnig facility made a effect of mastery of mathematic consept [4] to know how indirect effect socio economic status from parent to mastery of matematiical concept throuogh learnig facility. Recuperation. The samples are eighth grade students from three state junior high schools in subdistrict Kemayoran, Central Jakarta, they are State Junior High School 228 with 38 students, State Junior High Schools 269 with 23 students, and State Junior High School 79 with 27 Students, the total samples are 88 students. The data collection is done by using questionnaires and test techniques. Data analysis is used by method of line-analysis. The statistical testused the t test. The result of the research shows : (1) There is significant direct effect of parental socio economic towards students' mastery mathematical concepts. (2) There is significant direct effect of parental socio economic toward learning facilities. (3) There is significant effect of learning facilities towards students' mastery mathematical concept. (4) There is significant indirect effect of parental socio economic towards students' mastery mathematical concept through learning facilities.
\end{abstract}

Keywords: parental socioeconomic, learning facilities, mathematical concepts 


\section{PENDAHULUAN}

Tujuan pendidikan nasional berdasarkan UU RI No. 20 Tahun 2003 tentang Sistem Pendidikan Nasional adalah pendidikan nasional bertujuan untuk mengembangkan potensi peserta didik agar menjadi manusia yang beriman dan bertaqwa kepada Tuhan YME, berakhlak mulia, sehat, berilmu, cakap, kreatif, mandiri, dan menjadi warga negara yang demokratis serta bertanggung jawab. Tujuan pendidikan yang hendak dicapai pemerintah Indonesia adalah mencerdaskan kehidupan bangsa. Oleh karena itu pemerintah telah mengadakan perluasaan kesempatan memperoleh pendidikan bagi seluruh rakyat Indonesia.Hal ini sesuai dengan bunyi pasal 31 ayat 1 UUD 1945, yang menyatakan bahwa "Tiap-tiap warga Negara berhak mendapat pengajaran".

Seorang guru perlu memahami bunyi danisi pasal ayat Undang-Undang Dasar tersebut, setiap murid berhak mendapatkan pengajaran yang sama. Tugas dari seorang guru yaitu guru harus memberi pengajaran yang sama kepada murid yang berbedabeda. Perbedaan itu berasal dari lingkungan kebudayaan, lingkungan sosial, jenis kelamin, dan lain-lain. Salah satu tujuan siswa bersekolah adalah untuk mencapai prestasi belajar yang maksimal sesuai dengan kemampuannya. Matematika merupakan cabang ilmu yang sangat penting untuk disampaikan pada setiap jenjang pendidikan, mulai dari tingkat Sekolah Dasar (SD) sampai dengan Perguruan Tinggi. Hal ini dikarenakan matematika menjadi sumber ilmu lain, banyak ilmu yang penemuan dan pengembangannya bergantung dari matematika sehingga dijadikan pelajaran wajib yang mampu mengembangkan daya pikir manusia dan dapat dimanfaatkan untuk penerapan di bidang lain (Cahyani dan Masruroh, 2020) . Menurut Hudoyo (2005) bahwa matematika berkenaan dengan ide-ide dan konsep-konsep yang abstrak dan tersusun secara hierarki dan penalarannya deduktif. Konsep matematika tersusun secara hierarki, maka dalam belajar matematika tahapan konsep harus tersusun secara berurutan. Matematika seharusnya dipelajari secara sistematis dan teratur serta harus disajikan dengan struktur yang jelas dan harus disesuaikan dengan perkembangan intelektual siswa serta kemampuan prasyarat yag telah dimilikinya, dengan demikian pembelajaran matematika akan terlaksana secara efektif dan efisien.

Pemahaman konsep matematika terlihat dalam tujuan pertama pembelajaran matematika menurut Depdiknas (Permendiknas no 22 tahun 2006) yaitu memahami konsep matematika, menjelaskan keterkaitan antara konsep dan mengaplikasikan konsep atau algoritma secara luwet, akurat, efisien dan tepat dalam pemecahan masalah. Sesuai dengan tujuan pembelajaran matematika maka setelah proses pembelajaran siswa diharapkan dapat memahami suatu konsep matematika sehingga dapat menggunakan kemampuan tersebut dalam menghadapi masalahmasalah matematika. Jadi pemahaman konsep merupakan bagian yang paling penting dalam pembelajaran matematika. Menurut Zukardi (2003) Mata pelajaran matematika menekankan pada konsep artinya dalam mempelajari matematika siswa harus memahami konsep matematika terlebih dahulu agar dapat menyelesaikan soal-soal dan mampu mengaplikasikan pembelajaran tersebut dalam dunia nyata.

Pemahaman konsep siswa memiliki banyak faktor yang mempengaruhinya. Diantaranya adalah faktor internal dan eksternal. Faktor internal adalah faktor yang berasal dari dalam diri peserta didik sedangkan faktor eksternal adalah faktor yang berasal dari luar diri peserta didik. Faktor yang berasal dari luar meliputi faktor-faktor yang berhubungan dengan lingkungan sekolah, lingkungan masyarakat serta lingkungan keluarga (Slameto, 2015). Keluarga adalah lingkungan pertama dan utama bagi perkembangan individu. Sejak kecil anak tumbuh dan berkembang dalam lingkungan keluarga. Pendidikan keluarga merupakan bagian dari jalur pendidikan luar sekolah yang diselenggarakan dalam keluarga dan yang memberi keyakinan agama, nilai budaya, nilai moral dan keterampilan (UU RI No. 20 Tahun 2003). Oleh karena itu keluarga mempunyai peranan penting dalam pendidikan, 
sehingga latar belakang keluarga harus diperhatikan agar keberhasilan pendidikan dicapai secara maksimal.

Lingkungan keluarga memiliki pengaruh besar terhadap keberhasilan anak dalam belajar. Tinggi rendahnya pendidikan orang tua, besar kecilnya penghasilan, cukup atau kurangnya perhatian dan bimbingan itu mempengaruhi pemahaman konsep anak. Selain itu, faktor keadaan rumah juga turut mempengaruhi keberhasilan belajar, seperti besar kecilnya rumah tempat tinggal, ada atau tidak peralatan/media belajar juga turut menentukan keberhasilan seseorang (Dalyono, 2012). Kondisi ekonomi orang tua tersebut bukan hanya mempengaruhi gizi dan kesehatan anak, tetapi juga akan mempengaruhi kesempatan dan mutu belajar (Sukmadinata, 2005). Pada umumnya anak yang berasal dari keluarga menengah ke atas lebih banyak mendapatkan pengarahan dan bimbingan yang baik dari orang tua. Anak-anak yang berlatar belakang ekonomi rendah, kurang mendapat bimbingan dan pengarahan yang cukup dari orang tua mereka, karena orang tua lebih memusatkan perhatiannya pada bagaimana untuk memenuhi kebutuhan sehari-hari (Thohir dkk, 2016). Menurut Sumardi (2011) meyatakan bahwa pada umumnya anak yang berasal dari keluarga menengah keatas lebih banyak mendapatkan pengarahan dan bimbingan yang baik dari orang tua.Anak-anak yang berlatar belakang ekonomi rendah, kurang dapat mendapat bimbingan dan pengarahan yang cukup dari orang tua karena orang tua lebih memusatkan perhatiannya pada bagaimana untuk memenuhi kebutuhan sehari-hari. Tinggi rendahnya keadaan sosial ekonomi orang tua ditentukan oleh beberapa faktor diantaranya adalah tingkat pendidikan, jenis pekerjaan, tingkat pendapatan, kondisi lingkungan tempat tinggal, pemilikan kekayaan, dan partisipasi dalam aktivitas kelompok dalam komunitasnya (Ariyanto, 2012).

Faktor internal lainnya yaitu pemenuhan fasilitas belajar. Fasilitas belajar diidentikan juga dengan sarana prasarana pendidikan Peraturan Pemerintah Nomor 19 Tahun 2005 tentang Standar Nasional Pendidikan, Bab VIII Standar Sarana dan Prasarana pasal 42 menegaskan bahwa (1) Setiap satuan pendidikan wajib memiliki sarana yang meliputi perabot, peralatan pendidikan, media pendidikan, buku dan sumber belajar lainnya, bahan habis pakai, serta perlengkapan lain yang diperlukan untuk menunjang proses pembelajaran yang teratur dan berkelanjutan, (2) Setiap satuan pendidikan wajib memiliki prasarana yang meliputi lahan, ruang kelas, ruang pimpinan satuan pendidikan, ruang pendidik, ruang tata usaha, ruang perpustakaan, ruang laboratorium, tempat olahraga, tempat ibadah, dan ruang atau tempat lain yang diperlukan untuk menunjang proses pembelajaran yang teratur dan berkelanjutan. Fasilitas belajar merupakan semua perangkat peralatan, bahan, dan perabot yang secara langsung dapat digunakan dalam proses pendidikan (Sopiatin, 2010). Pemanfaatan fasilitas belajar diantaranya dapat memperlanjar dan meningkatkan proses belajar siswa, menimbulkan motivasi belajar. Siswa yang memiliki keluarga berstatus sosial ekonomi tinggi akan memiliki fasilitas belajar yang lebih lengkap dibandingkan dengan peserta didik yang berstatus sosial sedang. Begitu juga peserta didik yang memiliki keluarga berstatus sosial ekonomi lemah, fasilitas belajar yang dimiliki tidak akan selengkap yang dimiliki oleh peserta didik yang berstatus ekonomi sedang maupun tinggi (Fuady, 2016). Berdasarkan latar belakang diatas maka peneliti melakukan penelitian tentang "pengaruh pengaruh sosial ekonomi dan fasilitas belajar terhadap penguasaan konsep matematika siswa SMPN kecamatan kemayoran" dengan tujuan dari penelitian ini yaitu (1) untuk membuktikan pengaruh langsung sosial ekonomi orang tua terhadap penguasaan konsep matematika (2) membuktikan pengaruh langsung sosial ekonomi orangtua terhadap fasilitas belajar (3) membuktikan pengaruh langsung fasilitas belajar terhadap penguasaan konsep matematika (4) serta membuktikan pengaruh tidak langsung sosial ekonomi orangtua terhadap penguasaan konsep matematika melalui fasilitas belajar. 


\section{METODE}

Penelitian menggunakan metode survei dengan analisis jalur (Path analysys). Pendekatan dalam penelitian ini menggunakan pendekatan kuantitatif.Pendekatan yang dilakukan dengan pencatatan dan analisis data hasil penelitian secara eksak dan menganalisis datanya menggunakan perhitungan statistik (Sugiyono, 2019).Variabel yang diteliti menggunakan tiga variabel yaitu variabel bebas sosial ekonomi orang tua $\left(\mathrm{X}_{1}\right)$, variabel intervening fasilitas belajar $\left(\mathrm{X}_{2}\right)$, dan variabel terikat penguasaan konsep matematika (Y). Penelitian ini akan menguji pengaruh langsung antara variabel sosial ekonomi orang tua dan fasilitas belajar terhadap penguasaan konsep matematika secara bersama-sama.Variabel sosial ekonomi orang tua siswa dan fasilitas belajar menggunakan skala ordinal yaitu skala yang didasarkan pada ranking, diurutkan dari jenjang yang lebih tinggi sampai jenjang terendah atau sebaliknya (Riduwan, 2018) sedangkan penguasaan konsep matematika menggunakan skala numerik.
Populasi dalam penelitian ini meliputi tiga SMP di wilayah Kemayoran Jakarta Pusat yaitu SMPN 228 JAKARTA, SMPN 269 JAKARTA, SMPN 79 JAKARTA. Pengambilan sampel dilakukan dengan menggunakan teknik Proporsional Cluster Random Sampling dimana jumlah sampel dari setiap sekolah diambil secara proporsional berdasarkan perbandingan jumlah siswa setiap sekolah terhadap jumlah populasi keseluruhan, dengan teknik ini maka diperoleh anggota sampel dari masing-masing sekolah yaitu 38 siswa dari SMP Negeri 228, 23 siswa SMP Negeri 269, 27 siswa SMPN 79 Jakarta. Data variabel kriteria yang terdiri atas sosial ekonomi orang tua dan fasilitas belajar dikumpulkan menggunakan instrument penelitian berupa angket yang telah divalidasi, sedangkan penguasaan konsep matematika menggunakan instrument penelitian berupa tes pilihan ganda. Hubungan antara ketiga variabel penelitian ini dapat digambarkan dalam bentuk konstelasi permasalahan sebagai berikut:

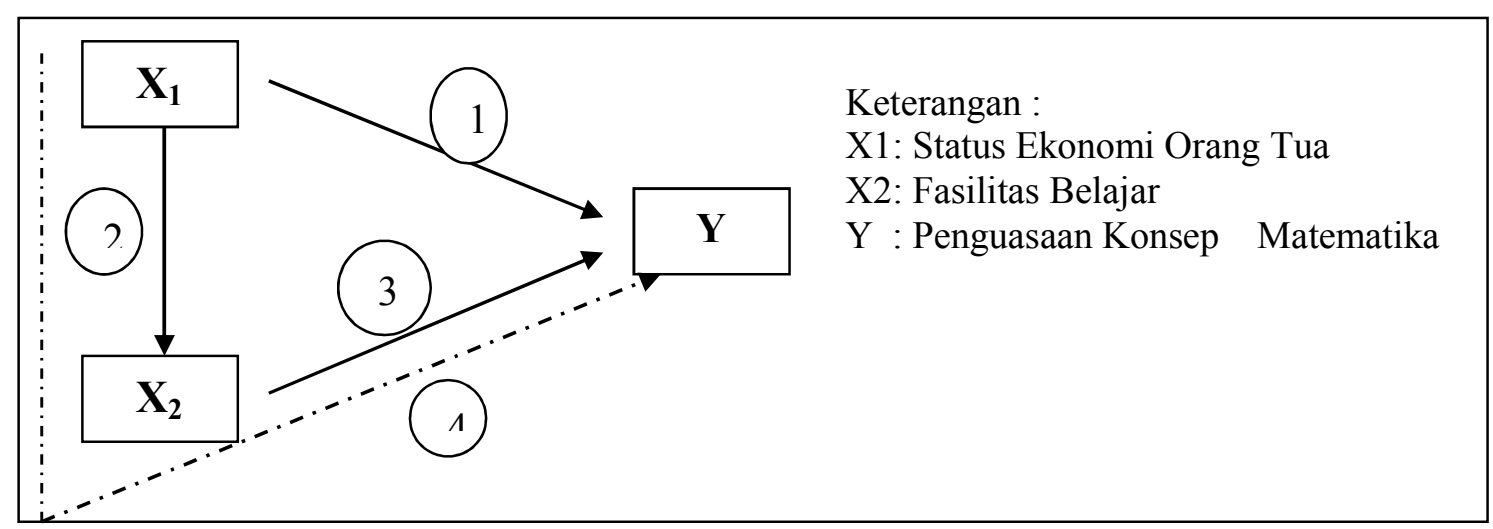

Gambar 1.Konstelasi Masalah Penelitian

Adapun pengaruh antar variabel :

1. Koefisien pengaruh langsung sosial ekonomi orang tua siswa terhadap penguasaan konsep matematika siswa.

2. Koefisien pengaruh langsung sosial ekonomi orang tua terhadap fasilitas belajar.

3. Koefisien pengaruh langsung fasilitas belajar terhadap penguasaan konsep matematika siswa.

4. Koefisien pengaruh langsung sosial ekonomi orang tua terhadap penguasaan konsep matematika melalui fasilitas belajar.

Data yang diperoleh dianalisis secara deskriptif dan inferensial. Analisis inferensial yang digunakan untuk menguji hubungan antar variabel dalam penelitian ini adalah Analisis Jalur (Path analysis). Penggunaan Analisis Jalur (Path Analysis) dilakukan dengan syarat bahwa (Sugiyono, 2019) : (a) Hubungan antar variabel yang 
akan dianalisis berbentuk linier, aditif, dan kausal. (b) Variabel-variabel yang residual tidak berkorelasi dengan variabel yang mendahuluinya, dan juga tidak berkorelasi dengan variabel yang lain. (c) model hubungan variabel hanya terdapat jalur kausal atau sebab akibat searah. (d) setiap variabel yang dianalisis adalah dua interval dan berasal dari sumber yang sama.

\section{HASIL PENELITIAN DAN PEMBAHASAN}

Analisis Data Sebelum Uji Analisis Jalur

Uji normalitas dilakukan untuk mengetahui data yang diperoleh berasal dari populasi berdistribusi normal atau tidak. Hal ini dilakukan sebagai syarat jika pengujian dilakukan dengan menggunakan statistik parametik. Menguji kenormalan hasil digunakan uji normalitas KolmogorovSmirnov pada taraf $\alpha=5 \%$ atau sama dengan 0.05. Apabila jumlah perhitungan lebih besar dari 0,05 maka dinyatakan normal, sebaliknya jika jumlah perhitungan lebih kecil dari 0,05 maka dinyatakan tidak normal (Ghozali, 2018). Uji normalitas disajikan pada tabel 1.

Berdasarkan tabel 1 data menunjukkan sosial ekonomi orang tua, fasilitas belajar dan penguasaan konsep matematika berdistribusi normal, nilai kolmogorovsmirnov $(\mathrm{p}>0.05)$.

Tabel 1. Uji Normalitas Status Ekonomi, Fasilitas Belajar dan Penguasaan Konsep Matematika

\begin{tabular}{|l|c|c|c|c|}
\hline \multicolumn{5}{|c|}{ One Sample Kolmogorv-Smirnov Test } \\
\hline \multirow{2}{*}{} & & $\begin{array}{c}\text { Sosial Ekonomi } \\
\text { Orang Tua }\end{array}$ & Fasilitas Belajar & $\begin{array}{c}\text { Penguasaan } \\
\text { Konsep } \\
\text { Matematika }\end{array}$ \\
\hline $\mathrm{N}$ & Mean & 73.88 & 75.41 & 88 \\
\hline $\begin{array}{l}\text { Normal } \\
\text { Parameter }\end{array}$ & Std. Deviation & 11.528 & 10.919 & 19.36 \\
\hline $\begin{array}{l}\text { Most Extreme } \\
\text { Differences }\end{array}$ & Absolute & 0.069 & 0.084 & 0.141 \\
\cline { 2 - 5 } & Positive & 0.042 & 0.056 & 0.141 \\
\cline { 2 - 5 } & Negative & -0.059 & -0.085 & -0.104 \\
\hline Kolmogorov-Smirnov Z & 0.651 & 0.783 & 1.324 \\
\hline \multicolumn{2}{|l|}{ Asymp. Sig (2-tailed) } & 0.790 & 0.571 & 0.060 \\
\hline Kesimpulan & Normal & Normal & Normal \\
\hline
\end{tabular}

Selanjutnya dilakukan uji linearitas. Menurut Ghozali (2018), uji linearitas digunakan untuk melihat apakah spesifikasi model yang dugunakan sudah benar atau tidak. Uji linearitas bertujuan untuk mengetahui apakah dua variabel mempunyai hubungan yang linear atau tidak secara signifikan. Uji ini biasanya digunakan sebagai prasyarat dalam analisis korelasi atau regresi linear. Pengujian pada SPSS dengan menggunakan Test for
Linearity dengan signifikansi 0,05 dengan ketentuan, jika nilai Sig. deviation from linearity $>0,05$, maka terdapat hubungan yang linear antara variabel bebas dengan variabel terikat. Sebaliknya, jika nilai Sig. deviation from linearity $<0,05$, maka tidak terdapat hubungan yang linear antara variabel bebas dengan variabel terikat. Tabel 2 merupakan tabel linearitas sosial ekonomi orang tua, fasilitas belajar, dan penguasaan konsep matematika.

Tabel 2. Uji Liniearitas Sosial Ekonomi Orang Tua, Fasilitas Belajar dan Penguasaan Konsep Matematika

\begin{tabular}{|c|c|c|}
\hline Garis Yang Diuji & $\begin{array}{c}\text { Sig. deviation from } \\
\text { linearity }\end{array}$ & Simpulan \\
\hline $\mathrm{X}_{1}$ dengan $\mathrm{Y}$ & 0.127 & Liniear \\
\hline $\mathrm{X}_{1}$ dengan $\mathrm{X}_{2}$ & 0.795 & Liniear \\
\hline $\mathrm{X}_{2}$ dengan $\mathrm{Y}$ & 0.139 & Liniear \\
\hline
\end{tabular}


Selanjutnya dilakukan uji kolinieritas. Uji kolinieritas bertujuan untuk mendeteksi apakah model regresi mengalami kolinieritas atau tidak. Uji kolinieritas menggunakan VIF. VIF merupakan singkatan dari Variance Inflation
Factor.Suatu model regresi dikatakan bebas dari kolinieritas, jika (1) Mempunyai nilai VIF di sekitar angka 1, (2) Mempunyai angka tolerance mendekati angka 1 . Menggunakan SPSS 20 diperoleh hasil sebagai berikut.

Tabel 3. Uji Kolinieritas

\begin{tabular}{|l|l|l|}
\hline \multirow{2}{*}{ Variabel Bebas } & \multicolumn{2}{|c|}{ Collinearity Statistics } \\
\cline { 2 - 3 } & Tolerance & VIF \\
\hline Sosial Ekonomi Orang Tua & 0.821 & 1.219 \\
\hline Fasilitas Belajar & 0.821 & 1.219 \\
\hline
\end{tabular}

Berdasarkan tabel 3, nilai tolerance yang diperoleh 0.821 masih dibawah angka 1 dan nilai VIF 1.219 mendekati angka 1, maka terdapat dugaan bebas dari adanya kolinieritas antara variabel sosial ekonomi orang tua siswa dengan fasilitas belajar.

Setelah penelitian dilakukan serta data yang diperoleh normal dan linier, baik itu data tentang status sosial ekonomi, fasilitas belajar, dan penguasaan konsep matematika, data tersebut belum dapat dipahami sebelum diadakan analisis data.
Untuk menganalisis data, peneliti melakukan analisis data dengan menggunakan spss 20. Hasil analisis tersebut dijelaskan sebagai berikut.

Analisis korelasi digunakan untuk menemukan koefisien korelasi yang selanjutnya koefisien korelasi tersebut akan digunakan untuk menentukan koefisien jalur. Pengujian analisis korelasi menggunakan SPSS 20 sebagai alat bantu dengan hasil sebagai berikut.

Tabel 4. Hasil Analisis Korelasi

\begin{tabular}{|l|c|c|}
\hline \multicolumn{1}{|c|}{ Hubungan Antar Variabel } & Sig. (1-tailed) & Pearson Correlation \\
\hline $\begin{array}{l}\text { Sosial Ekonomi Orang tua dengan } \\
\text { Penguasaan Konsep Matematika } \\
\text { Siswa }\end{array}$ & 0.000 & 0.597 \\
\hline $\begin{array}{l}\text { Sosial Ekonomi Orang tua dengan } \\
\text { Fasilitas Belajar Siswa }\end{array}$ & 0.000 & 0.423 \\
\hline $\begin{array}{l}\text { Fasilitas Belajar Siswa dengan } \\
\text { Penguasaan Konsep Matematika } \\
\text { Siswa }\end{array}$ & 0.000 & 0.703 \\
\hline
\end{tabular}

Berdasarkan perhitungan yang didasarkan oleh koefisien korelasi diperoleh koefisien jalur, koefisien jalur menunjukkan kuatnya pengaruh variabel independen terhadap variabel dependen. Jika koefisien jalur rendah di bawah 0.05 maka jalur tersebut dianggap tidak signifikan dan dapat dihilangkan (Sudjana, 2010). Koefisien jalur didapat dengan menggunakan SPSS 20, nilai koefiesi jalur dapat dilihat pada tabel berikut ini. 
Tabel 5. Koefisien Analisis Jalur

\begin{tabular}{|l|c|c|c|}
\hline \multicolumn{1}{|c|}{ Variabel } & $\begin{array}{c}\text { Standardized } \\
\text { Coefficients }\end{array}$ & Sig. & $\mathrm{t}$ \\
\cline { 2 - 4 } & Beta & & \\
\hline $\begin{array}{l}\text { Sosial Ekonomi Orangtua } \\
\text { terhadap Fasilitas Belajar }\end{array}$ & 0.423 & 0.000 & 4.335 \\
\hline $\begin{array}{l}\text { Sosial Ekonomi Orangtua } \\
\text { terhadap Penguasaan } \\
\text { Konsep Matematika }\end{array}$ & 0.364 & 0.000 & 4.827 \\
\hline $\begin{array}{l}\text { Fasilitas Belajar terhadap } \\
\text { Penguasaan Konsep } \\
\text { Mateematika }\end{array}$ & 0.548 & 0.000 & 7.268 \\
\hline
\end{tabular}

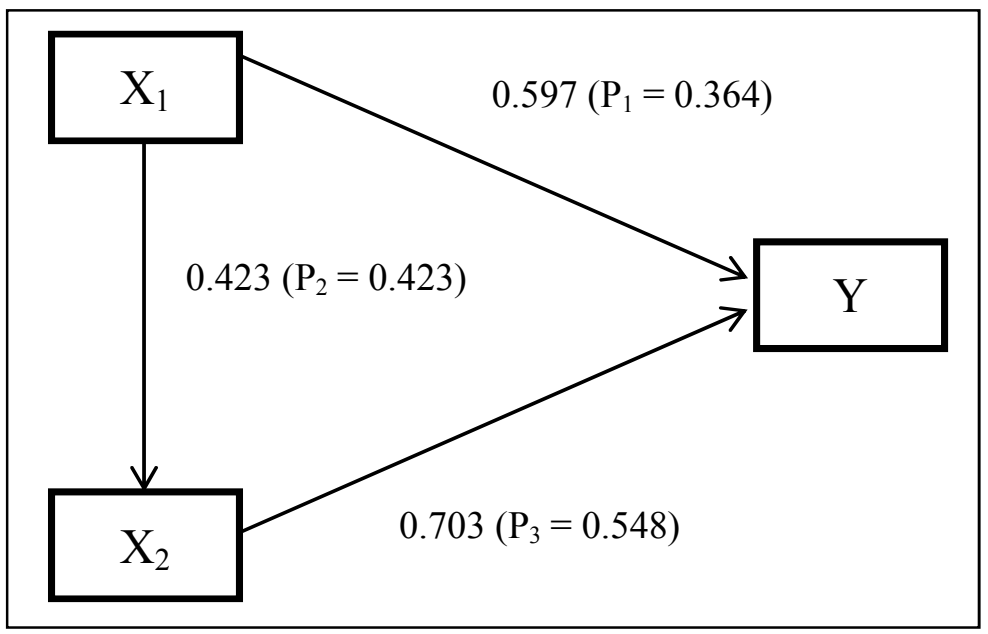

Gambar 2. Diagram Koefisien Korelasi dan Koefisien Jalur

Analisis Data Pengaruh Sosial Ekonomi Orangtua terhadap Penguasaan Konsep Matematika Siswa

Berdasarkan analisis jalur diketahui bahwa koefisien jalur variabel sosial ekonomi orang tua terhadap penguasaan konsep matematika siswa $p_{1}=0,364$, Untuk $\alpha=0.05$ dan $\mathrm{dk}=\mathrm{n}-\mathrm{k}-1=88-2-1=85$ pada uji dua pihak diperoleh nilai $t_{\text {tabel }}=t_{t}=$ 1,988. Oleh karena nilai $t_{h}>t_{t}(4,827>$ 1,988) maka $\mathrm{H}_{1}$ diterima dan disimpulkan terdapat pengaruh langsung Sosial Ekonomi Orang tua terhadap Penguasaan Konsep Matematika Siswa.

Berdasarkan hasil perhitungan dengan menggunakan SPSS 20, maka hasil penelitian sesuai dan sejalan dengan pengajuan hipotesis penelitian yang menyatakan bahwa terdapat pengaruh langsung sosial ekonomi orang tua terhadap penguasaan konsep matematika siswa. Hal ini sejalan dengan penelitian ariyanto
(2012) yang mengatakan anak dengan berstatus sosial ekonomi rendah cenderung untuk membantu orang tuanya dalam mencukupi kebutuhan keluarganya, kesempatan untuk belajar berkurang yang berakibat kepada penguasaan konsep yang tidak optimal. Menurut Dalyono (2012) ada beberapa faktor yang mempengaruhi penguasaan konsep siswa yakni salah satunya faktor keluarga, faktor orang tua sangat besar pengaruhnya terhadap keberhasilan anak dalam belajar.Tinggi rendahnya pendidikan orang tua, besar kecilnya penghasilan, cukup ataukurang perhatian dan bimbingan orang tua, dan sebagainya, semuanya itu juga turut menentukan keberhasilan belajar anak. Berdasarkan temuan penelitian tersebut bahwa penguasaan konsep matematika siswa dapat dipengaruhi oleh sosial ekonomi orang tua. 
Analisis Sosial Ekonomi Orangtua terhadap Fasilitas Belajar

Berdasarkan analisis jalur diketahui bahwa koefisien jalur variabel sosial ekonomi orang tua terhadap fasilitas belajar $p_{1}=0,423$, untuk $\alpha=0,05$ dan $\mathrm{dk}=\mathrm{n}-\mathrm{k}-1=$ $88-2-1=85$ pada uji dua pihak diperoleh nilai $t_{\text {tabel }}=t_{t}=1,988$. Oleh karena nilai $t_{h}>$ $t_{t}(4,335>1,988)$ maka $H_{1}$ diterima dan disimpulkan terdapat Pengaruh Langsung Sosial Ekonomi Orang tua terhadap Fasilitas Belajar. Ada banyak faktor yang mempengaruhi sosial ekonomi orang tua salah satunya adalah fasilitas belajar. Menurut Slameto (2015) menerangkan bahwa sosial ekonomi orang tua sangat penting dalam menentukan keberhasilan seorang anak, orang tua dengan keadaan ekonomi yang cukup, sangat mempengaruhi dalam memberikan sarana dan prasarana pendidikan yang memadai, sebaliknya orang tua dengan keadaan ekonomi yang lemah akan kurang memberikan perhatian dalam hal memberikan sarana dan prasarana pendidikan.

Analisis Pengaruh Fasilitas Belajar terhadap Penguasaan Konsep Matematika Siswa

Berdasarkan analisis jalur diketahui bahwa koefisien jalur variabel fasilitas belajar terhadap penguasaan konsep matematika siswa $p_{3}=0,548$, untuk $\alpha=$ 0,05 dan $\mathrm{dk}=\mathrm{n}-\mathrm{k}-1=88-2-1=85$ pada uji dua pihak diperoleh nilai $t_{\text {tabel }}=t_{t}=1,988$. Oleh karena nilai $t_{h}>t_{t}(7,268>1,988)$ maka $\mathrm{H}_{1}$ diterima dan disimpulkan terdapat Pengaruh Langsung Fasilitas Belajar terhadap Penguasaan Konsep Matematika Siswa. Fasilitas belajar adalah segala alat dan sarana yang diperlukan untuk menunjang kegiatan belajar anak. Fasilitas belajar berupa ruang belajar anak, bukubuku, alat-alat belajar dan lain-lain. Pemenuhan fasilitas belajar sangat penting bagi anak karena akan dapat mempermudah baginya untuk belajar dengan baik.

Menurut Muhibbin (2013) menyatakan bahwa semakin lengkap alat-alat pelajarannya akan semakin dapat orang belajar dengan sebaik-baiknya, sebaliknya kalau alat-alatnya tidak lengkap maka hal ini merupakan gangguan di dalam proses belajar, sehingga hasilnya akan mengalami gangguan. Tersedianya fasilitas belajar yang memadai akan berdampak positif dalam aktivitas belajar anak. Fasilitas belajar seperti buku termasuk unsur yang sangat penting dalam upaya meningkatkan penguasaan konsep anak, tercukupinya buku yang merupakan salah satu sumber belajar akan memperlancar proses belajar mengajar di dalam kelas dan mempermudah dalam belajar di rumah dan juga akan dapat meningkatkan semangat belajar anak.

Siswa yang memiliki keluarga berstatus sosial ekonomi tinggi akan memiliki fasilitas belajar yang lebih lengkap dibandingkan dengan peserta didik yang berstatus sosial sedang. Begitu juga peserta didik yang memiliki keluarga berstatus sosial ekonomi lemah, fasilitas belajar yang dimiliki tidak akan selengkap yang dimiliki oleh peserta didik yang berstatus ekonomi sedang maupun tinggi (Fuady, 2016). Prihatini (2017) yang menyatakan bahwa terdapat pengaruh yang signifikan antara fasilitas belajar dengan hasil belajar sebesar $58,16 \%$. Sehingga terdapat dugaan bahwa fasilitas belajar memiliki pengaruh terhadap pencapaian prestasi belajar siswa.

Analisis Pengaruh Sosial Ekonomi Orang Tua Terhadap Penguasaan Konsep Matematika Siswa Melalui Fasilitas Belajar

Berdasarkan analisis jalur diketahui bahwa koefisien jalur variabel sosial ekonomi orang tua terhadap penguasaan konsep matematika siswa melalui fasilitas belajar $p_{123}=p_{2} \times p_{3}=0,423 \times 0,548=0,232$. Jika dibandingkan dengan nilai $p_{31}$ maka nilai $p_{123}=0,232<p_{1}=0,364$. Hal ini mengintrepretasikan bahwa variabel intervening tidak berpengaruh secara signifikan terhadap penguasaan konsep matematika siswa.Untuk $\alpha=0,05 \mathrm{dan} \mathrm{dk}=$ $\mathrm{n}-\mathrm{k}-1=85$ pada uji dua pihak diperoleh nilai $t_{\text {tabel }}=t_{t}=1,988$. Oleh karena nilai $t_{h}>$ $\mathrm{t}_{\mathrm{t}}(3,06>1,988)$ maka $\mathrm{H}_{1}$ diterima dan dapat disimpulkan terdapat pengaruh tidak langsung yang signifikan Sosial Ekonomi Orang tua terhadap Penguasaan Konsep Matematika Siswa melalui Fasilitas Belajar.

Berdasarkan temuan penelitian ini menunjukkan peningkatan penguasaan konsep matematika anak dapat dilakukan dengan melalui fasilitas belajar anak. 
Keadaan ekonomi keluarga memiliki peranan terhadap perkembangan anak, misalnya keluarga yang perekonomiannya cukup menyebabkan lingkungan materialnya yang dihadapi keluarganya akan lebih luas, sehingga ia dapat kesempatan yang luas untuk mengembangkan kecakapannya. Kecakapan tersebut dapat dikembangkan jika terdapat perhatian penuh dari orang tua, sebaliknya keluarga dengan ekonomi kekurangan akan fokus terhadap pekerjaannya dan kurang memberikan perhatian dan bimbingan kepada anak (Safitri \& Kustini, 2014). Semakin lengkap kebutuhan pendidikan anak maka akan semakin meningkat pula keinginan siswa untuk belajar serta hasil belajar anak. Fasilitas belajar juga mempengaruhi hasil belajar anak. Salah satu fasilitas belajar adalah alat-alat pelajaran. Memiliki alat-alat dan perlengkapan yang diperlukan untuk belajar ditambah dengan cara mengajar yang baik dari guru-gurunya, kecakapan guru dalam menggunakan alat-alat tersebut, akan mempermudah dan mempercepat belajar anak (Muhammad, dkk: 2019).

\section{SIMPULAN}

Berdasarkan pengolahan data, maka dapat disimpulkan bahwa (1) Terdapat pengaruh langsung yang signifikan sosial ekonomi orang tua terhadap penguasaan konsep matematika. (2) Terdapat pengaruh langsung yang signifikan sosial ekonomi orang tua terhadap fasilitas belajar. (3) Terdapat pengaruh langsung yang signifikan fasilitas belajar terhadap penguasaan konsep matematika siswa. (4) Terdapat pengaruh tidak langsung sosial ekonomi orang tua terhadap penguasaan konsep matematika melalui fasilitas belajar.

\section{REFERENSI}

Ariyanto, Dwi. (2012). Pengaruh Antara Motivasi Belajar Siswa dan Tingkat Ekonomi Kelaurga Terhadap Prestasi Belajar Siswa Kelas X Jurusan Teknik Gambar Bangunan SMK Negeri 4 Semarang Tahun Ajaran 2011/2012. Jurnal UNNES. I(1): 38-42.

Cahyani\&Masruroh. (2020). Pengaruh Kemampuan Awal dan Kecerdasan
Emosional terhadap Komunikasi Matematis. Prosiding Seminar Sains Universitas Indraprasta PGRI, Jakarta: 20 Juni 2021. Hal. 462-471.

Dalyono.(2012). Psikologi Pendidikan. Jakarta: Rineka Cipta.

Fuady. (2016). Pengaruh Tingkat Sosial Ekonomi Keluarga terhadap Hasil Belajar Matematika ditinjau dari Motivasi Belajar pada Siswa Kelas VIII SMP Negeri 1 Colomadu tahun 2015/2016. Jurnal Unversitas Muhamadiyyah Surakarta. III(2): 2-11.

Ghozali, Imam. (2018). Aplikasi Analisis Multivariate dengan Program IBM SPSS 25. Semarang: Badan Penerbit Universitas Diponegoro.

Hudoyo.(2005). Belajar Mengajar Matematika. Jakarta: Departemen Pendidikan dan Kebudayaan.

Muhamad, H., Agus, E., \& Basori. (2019). Pengaruh Fasilitas Belajar Berbasis Teknologi Terhadap Prestasi Belajar Siswa. Jurnal Ilmiah Pendidikan Teknik Kejuruan, 12(2), 56-64.

Muhibbin S. (2013). Psikologi Pendidikan dengan Pendekatan Baru. Bandung: Remaja Rosdakarya.

Peraturan Pemerintah Republik Indonesia Nomor 19 tahun 2005 tentang Standar Nasional. (2005). Jakarta: Depdikbud.

Peraturan Menteri Pendidikan Nasional No 22 tahun 2006 tentang Standar Isi. (2006). Jakarta: Depdikbud.

Prihatin, M. S. (2017). Pengaruh Fasilitas Belajar, Gaya Belajar Dan Minat Belajar Terhadap Hasil Belajar Mata Pelajaran Ekonomi Siswa Kelas X IIS SMA Negeri 1 Seyegan. Jurnal Pendidikan dan Ekonomi, 6(5).

Riduwan. (2018). Skala Pengukuran Variabel-variabel Penelitian.Bandung: Alfabeta.

Safitri, F. N., \& Kustini, S. (2014). Pengaruh Minat Belajar, Kondisi Sosial Ekonomi Orang Tua, Dan Lingkungan Sekolah Terhadap Prestasi Belajar Ekonomi Pada Siswa Kelas XI IPS SMA Negeri 4 Magelang Tahun Ajaran 2013/2014. Economic Educational Journal, 3(2).

Slameto.(2015). Belajar dan Faktor-Faktor yang Mempengaruhinya. Jakarta: 
Rineka Cipta.

Sopiatin, Popi. (2010). Manajemen Belajar Berbasis Kepuasan Siswa. Bogor: Ghalia Indonesia.

Sugiyono.(2019). Metode Penelitian Kuantitatif Kualitatif Dan R\&D. Bandung : Alfabeta.

Sudjana. (2010). Metode Statistika. Bandung: Tarsito.

Sukmadinata, N. S. (2005). Landasan Psikologi Proses Pendidikan. Bandung: PT Remaja Rosdakarya.

Sumardi. (2011). Kemiskinan dan Kebutuhan Pokok. Jakarta: CV Rajawali Citra Press.

Suryabrata S. (2018). Metodologi Penelitian. Jakarta : PT. RajaGrafindo Persada.

Thohir, M., Soesatyo, Y., \& Harti H. (2016). Pengaruh Status Sosial Ekonomi
Orang Tua, Literasi Ekonomi dan Percaya Diri terhadap Minat Wirausaha. Jurnal Ekonomi Pendidikan dan Kewirausahaan, 4(2).

Undang-Undang Republik Indonesia Nomor 20 Tahun 2003 tentang Sistem Pendidikan Nasional. (2003). Jakarta: Depdikbud.

Wahyuni, Sri. (2010). Hubungan Status Sosial Ekonomi Orang Tua Dan Pemanfaatan Media Belajar Dengan Prestasi Belajar Pada Siswa Kelas Xi Sma Batik 2 Surakarta Tahun Ajaran 2010/2011. Tesis tidak dipublikasikan, Surakarta: Universitas Sebelas Maret.

Zulkardi.(2003). Pendidikan Matematika di Indonesia: Beberapa Permasalahan dan Upaya Penyelesaiannya. Palembang: Universitas Sriwijaya. 